\title{
Examining the influence of settlement morphology and separation zones policies on the availability of shallow coal resources in the United Kingdom
}

Authors: Emma J Bee ${ }^{1}$ and Joseph M Mankelow ${ }^{1}$

${ }^{1}$ British Geological Survey

Correspondence: Emma Bee, British Geological Survey, Environmental Science Centre, Nicker Hill, Keyworth, Nottingham, NG12 5GG, UK.

Email: ebee@bgs.ac.uk

Tel: +44(0)1159363044.

\section{Keywords}

Coal; Policy; UK; Settlements; Energy; Shape.

\section{Highlights}

- The shape of a settlement can affect the area of a separation zone.

- Elongated settlements have a greater influence on the area of separation.

- Settlement shape has the potential to influence the surface area of shallow coal resource sterilised.

- Results can help inform policy development in the UK and abroad.

\begin{abstract}
In 2013, demand for coal in the UK was 60 million tonnes. Of this, 12.7 million tonnes (21\%) came from indigenous sources; the majority of which was from surface mining (8.6 million tonnes). Many planning applications for surface mining of coal and the coal extraction that follows, are often a source of conflict with the communities who live within shallow coalfield areas. Policies which enforce a gap, or 'separation zone', between communities and surface coal mining operations exist in Wales and Scotland, but do not exist in England. This paper examines the effect of applying separation zones on the availability of shallow coal resources within two study areas; one within the South Wales Coalfield, the other within the Midlands Coalfield (comprising the Yorkshire, Nottinghamshire and North Derbyshire Coalfield areas). Density profiles and a shape-index algorithm are used to compare and contrast settlement morphology (i.e. shape or footprint) and distribution to determine whether they have a bearing on the areal extent of any potential separation zone applied. The implications on the availability of shallow coal resources of applying different separation zone distances around settlements within these two areas are explored. Results reveal that although the settlement morphology is important in determining the area of the separation zone, and has greatest influence in the South Wales Coalfield, the area of coal resource sterilised by the application of separation zones is greatest in the Midlands Coalfield due to it having a higher proportion of urban development situated on the surface extent of the shallow coal resource.
\end{abstract}




\section{INTRODUCTION}

\subsection{Coal production in the UK}

The UK has a long history of coal production, reaching a peak of 287 million tonnes in 1913. Thereafter output declined, due in part to loss of export markets during, and subsequent to, the First World War. Despite this decline, coal remained the UK's most important primary fuel until 1971, when it was overtaken by petroleum (Chapman et al., 2006). The UK remained a net exporter of coal until early 1983 (British Geological Survey, 2010). After that date, mine closures caused output to fall and imports rose rapidly. This decline was accelerated in the 1990's due to the 'dash for gas' which resulted out of concerns about carbon emissions and climate change, as well the exhaustion of reserves in older pits and the lack of (capital) investment to develop new ones during a period of environmental and policy uncertainty (UK Minerals Forum, 2014a). In 2001, imports exceeded indigenous production for the first time; a trend that has continued to date (Figure 1).

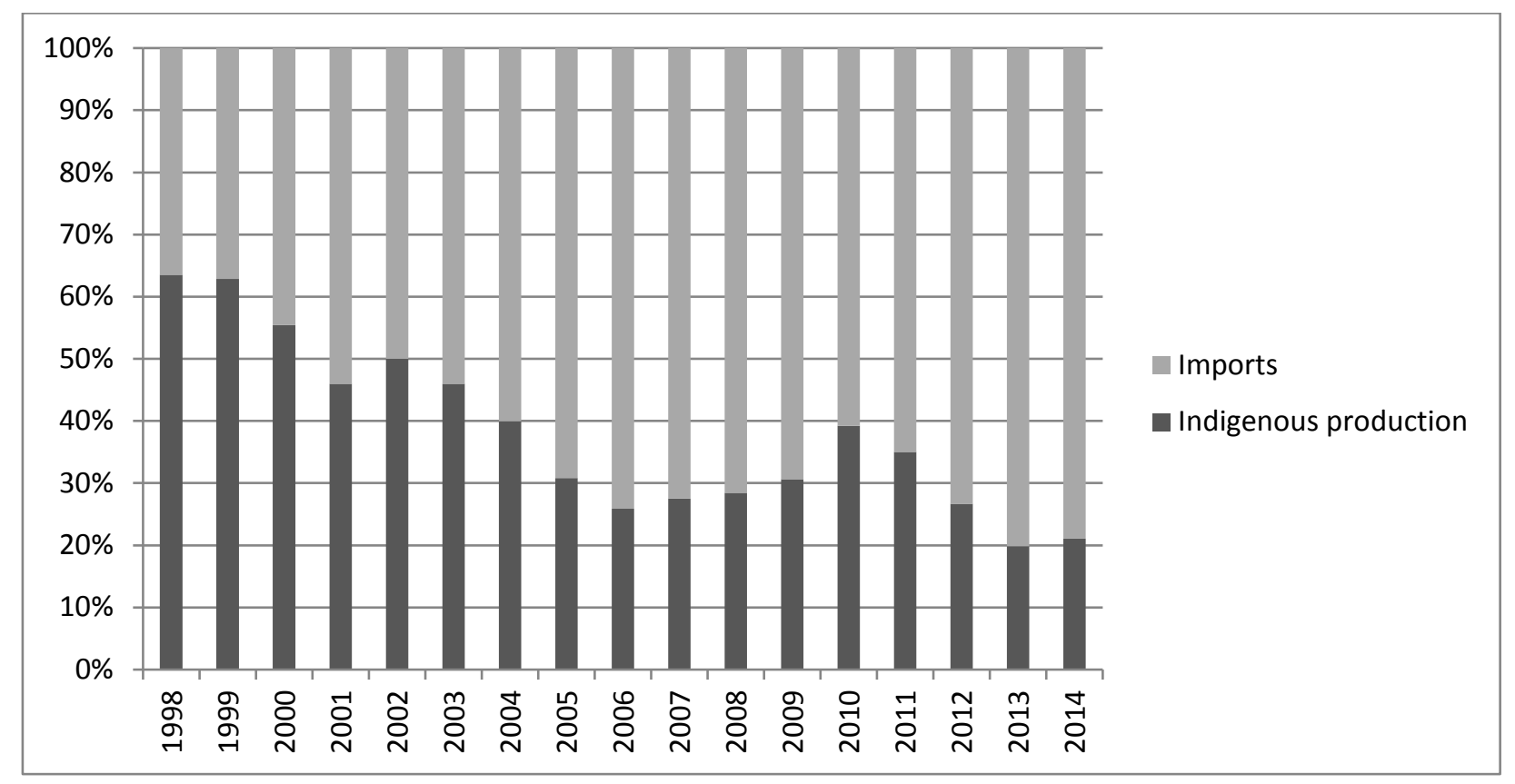

Figure 1. Percentage supply of coal from imports versus indigenous production in the UK from 1998 to 2014. Source: DECC (2015a).

In 2008, the British Government introduced the Climate Change Act which set a legally binding target of reducing the nation's $\mathrm{CO}_{2}$ emissions to at least $80 \%$ of the 1990 baseline by 2050 (British Parliament, 2008). The Energy Act 2013 introduced a switch in the main sources of electricity generation away from dependence on fossil fuels to lower carbon generation (TSO, 2013). This means that any future long term use of coal for energy production would, therefore, need to be tied to Carbon Capture and Storage (CCS) technology (UK Minerals Forum, 2014b, Hammond and Spargo, 2014). Furthermore, the effects of the Large Combustion Plant Directive (LCPD) (2001/80/EC) 
issued by the European Parliament in 2001, which requires member states to legislatively limit emissions of sulphur dioxide, nitrogen oxides and dust from combustion plants with a thermal capacity of 50MW or greater, are now coming in to force. Under the terms of the LPCD, combustion plants licensed before $1^{\text {st }}$ July 1987 can either opt to comply with the emissions limits or 'opt out' and close by the end of 2015. The remaining plants are subject to the LCPD and must comply with specific emissions limits (DEFRA 2010). In the UK, several core coal-fired power stations have 'opted out' of the LCPD. The 'opt out' option was the preferred option for many power plant operators, where the investment required to meet the new emissions limits was not considered to be viable.

In 2013, demand for coal in the UK was 60 million tonnes. Of this, 12.7 million tonnes (21\%) came from indigenous sources; the majority of which was from surface mining (8.6 million tonnes) (DECC 2014a, 2014b). During 2013 a number of deep mines closed (including the Daw Mill Colliery in Warwickshire after a major fire) and some surface mines went into liquidation. In 2014, electricity generation from coal in the UK fell by $36 \%$, as several plants closed or switched to predominantly burn biomass (DECC, 2015b). The closure of three other deep coal mines in 2015: Hatfield (June 2015); Thoresby (July 2015); and Kellingley (December 2015) means that the UK no longer mines deep coal.

Despite these closures, increasing demand for electricity is likely to mean there will remain a market (albeit declining) for coal for power generation in the UK for at least the next 20 years (UK Minerals Forum, 2014a). In particular coal produced at surface, remains an important part of the energy mix in the UK today (Figure 2 and Figure 3). The UK remains heavily reliant on coal, in particular, to meet its energy needs during the winter months where $44 \%$ of electricity generated is from coal (UK Minerals Forum, 2014a). 


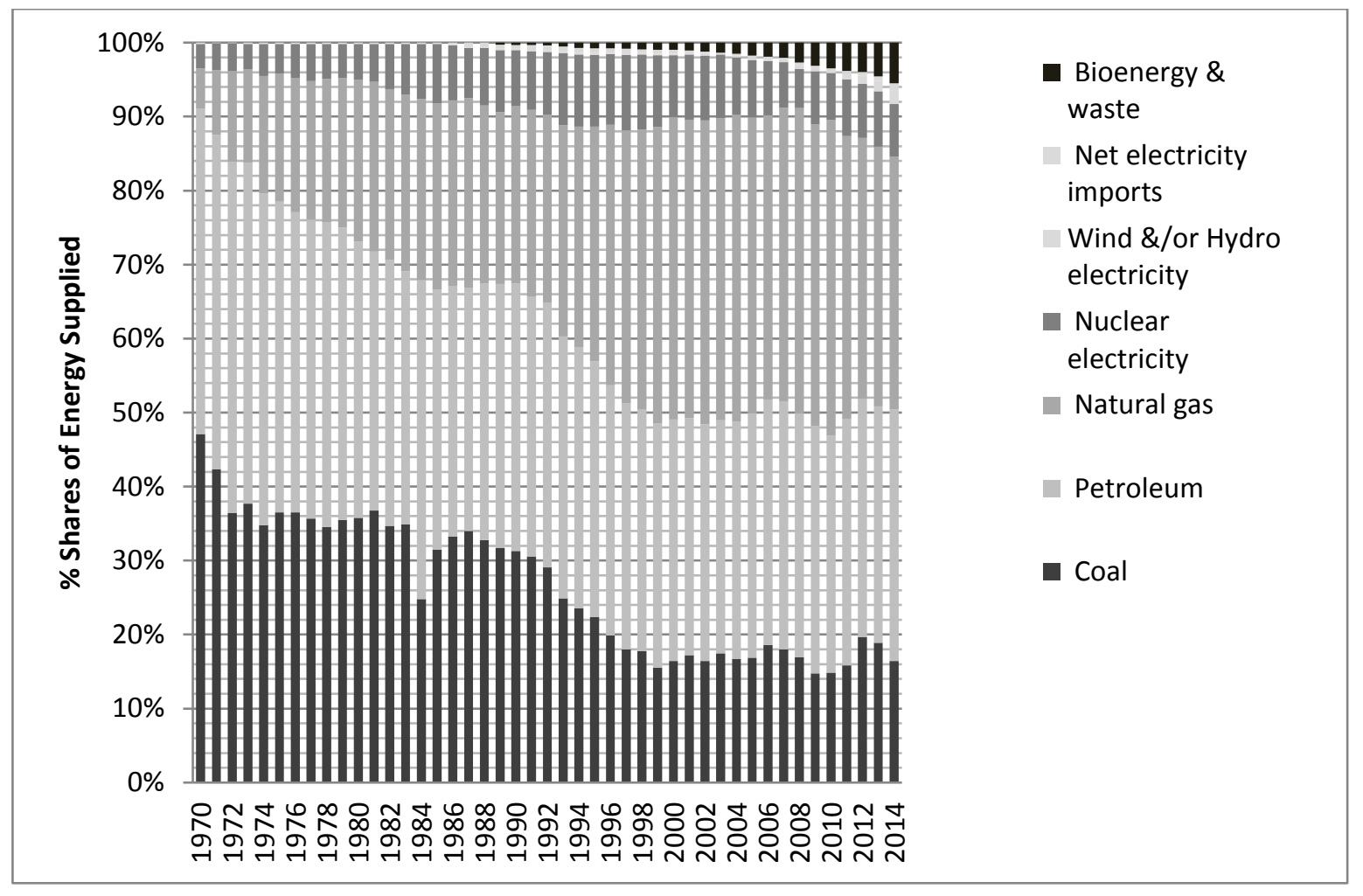

Figure 2. Percentage shares (energy supplied basis) of UK energy from 1970 to 2014. The black bars at the bottom of the graph denote coal. Source: DECC (2015c).

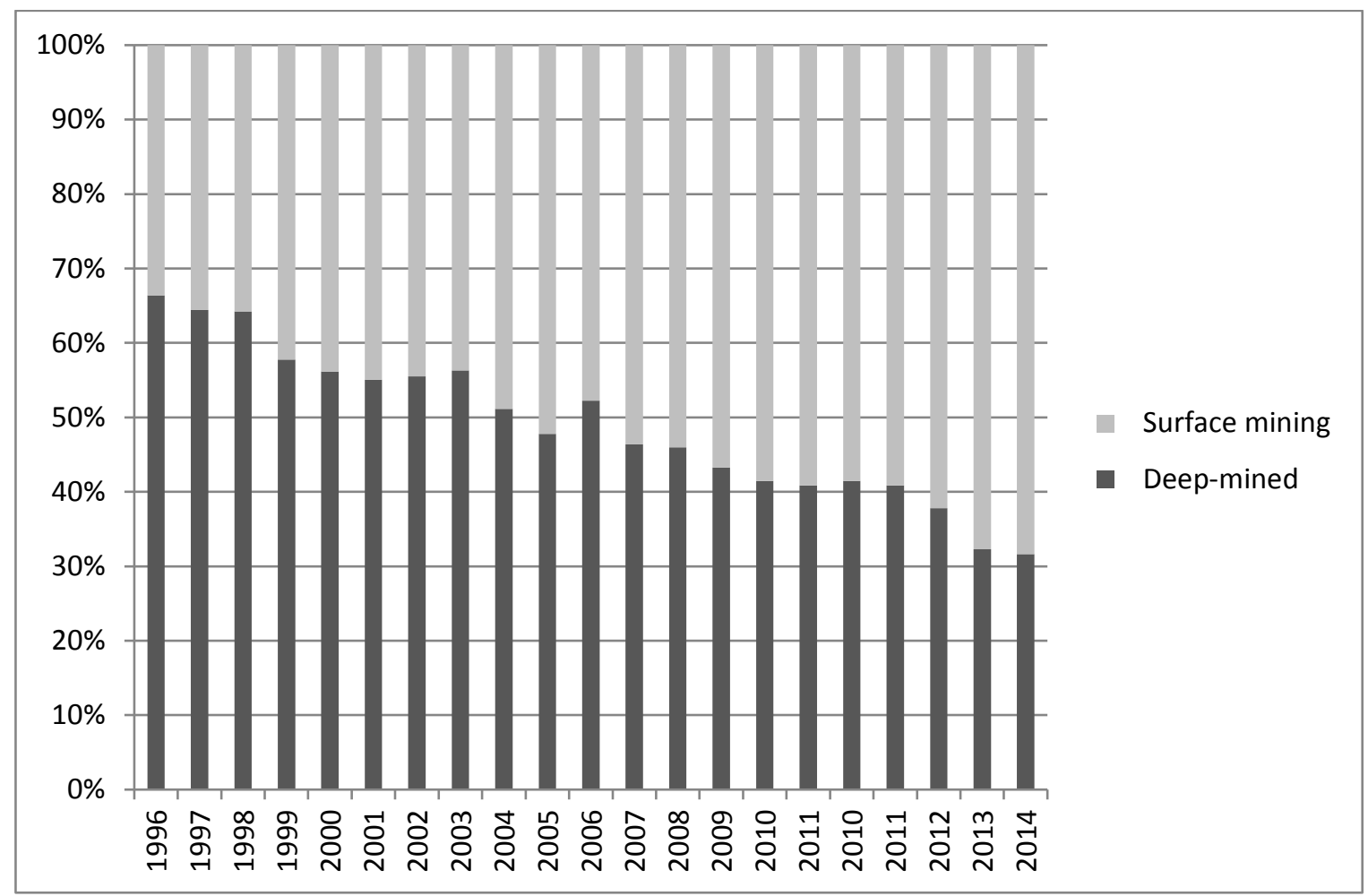

Figure 3. Proportion of indigenous coal supplied from deep mining and surface mining. Source: DECC (2014b). 
Extensive resources of coal, both near surface and underground, still exist within the coalfield areas of the UK (Figure 4). However it is unlikely that any new deep mines would be economically viable in the immediate future; therefore interest in coal extraction will be mainly confined to shallow coal resources that can be worked by surface mining methods (British Geological Survey, 2010).

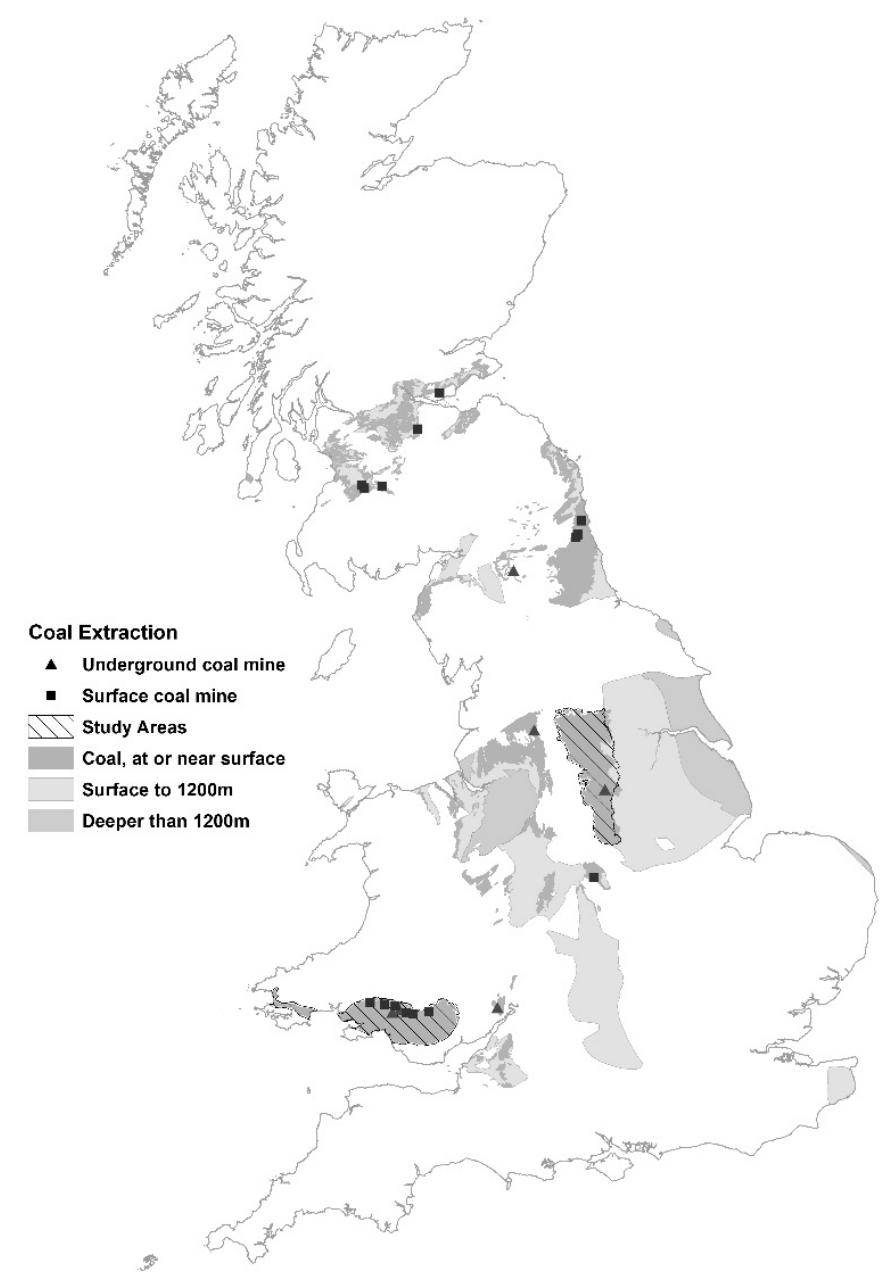

Contains Ordnance Survey data @ Crown copyright and database right 2016. BGS mineral resource data, BGS @ NERC. Information on CBM and UGC potential reproduced from UK Coal Resource for New Exploitation Technologies : Mining and New Technologies Summary Map Scale 1:1 750 000 and 1:600 000 by permission of AEA Technology, DTI and BGS.

Figure 4. Distribution of coal resources in the UK including producing and developing mines. November 2014. The underground coal mining shown refers to small mines, with adit working, rather than deep coal mines. 


\subsection{Separating communities from coal working}

Although several developed countries around the world utilise policies which seek to protect mineral resources from incompatible development (Wrighton et al. 2014 and Wagner et al. 2006) it is not apparent that many have introduced planning policies which enforce gaps, or 'separation zones', between surface mining and residential settlements. Western Australia (WA) provides a rare example outside of the UK where separation zones (or in this case Special Control Areas) for the extraction of 'basic raw materials' have been implemented (Western Australian Planning Commission, Department of Planning, 2016). Although not specifically related to surface mining, Queensland, Australia also provides an example of where separation zones (or buffer areas) are applied through policy to separate 'good quality agricultural land' from encroachment by residential activity in a similar manner to the adoption of mineral safeguarding in the UK. (Department of Natural Resources, Queensland, 1997).

Within the UK, actual separation zones have been recommended by the Welsh Assembly Government through Minerals Technical Advice Note (MTAN) 2: Coal (2009) and by the Scottish Government in Scottish Planning Policy (SPP, 2014) to help protect communities from the impacts of surface coal working. The Welsh MTAN (2009) specifically states that "coal working will generally not be acceptable within 500 metres $(\mathrm{m})$ of settlements". Whilst in SPP (2010) "Surface coal extraction is unlikely to be environmentally acceptable if proposed site boundaries are within $500 \mathrm{~m}$ of the edge of a community". Whilst the SPP and MTAN do not preclude coal working within a separation zone, given the wording of the respective policies, obtaining permission for coal working within these areas will be more difficult. Although there is no equivalent coal separation zone policy in England to date, a Private Members’ Bill - Planning (Opencast Mining Separation Zones), was introduced to the House of Commons on the 30 June 2010 proposing a $500 \mathrm{~m}$ separation zone in England. Its second reading occurred on 11 February 2011 (House of Commons. 2011a, 2011b). The Bill failed to complete its passage through Parliament before the end of session and therefore made no further progress, meaning that there is no equivalent 'enforced' separation zone policy in England.

Despite the limited examples of separation zone polices being implemented outside of the UK, many developed nations, including the UK, ensure that Environmental Impact Assessments (EIAs), which include noise and dust assessments, are carried out for certain types of development. For example, within the European Union, Directive 2011/92/EU: 'on the assessment of the effects of certain public and private projects on the environment' makes EIAs mandatory for quarries and open cast mining over 25 hectares (European Parliament, 2011). Guidance from these site-specific assessments have to 
be adhered to for development to take place and as such, the distance between residential areas and mine working is controlled by local conditions (landscape and environment).

\subsection{The influence of settlement morphology on the area of separation zones}

Settlement morphology and their spatial distribution vary considerably in different parts of the UK. This study assessed whether these differences affect the proportional amounts of coal resource sterilised in different regions when separation zones are applied to enforce a gap between urban areas and coal workings. Analysis of two similarly sized areas, but with different geometric shapes (one elongated, the other circular), as shown in Figure 5 and Table 1, would suggest that settlement morphology can influence the area of a separation zone, and therefore potentially affect the amount of shallow coal resource that is sterilised. The application of a separation zone around the elongated shape has the effect of creating a larger combined area (or potential sterilisation area) than when the same separation zone distance is applied around the circular shape.
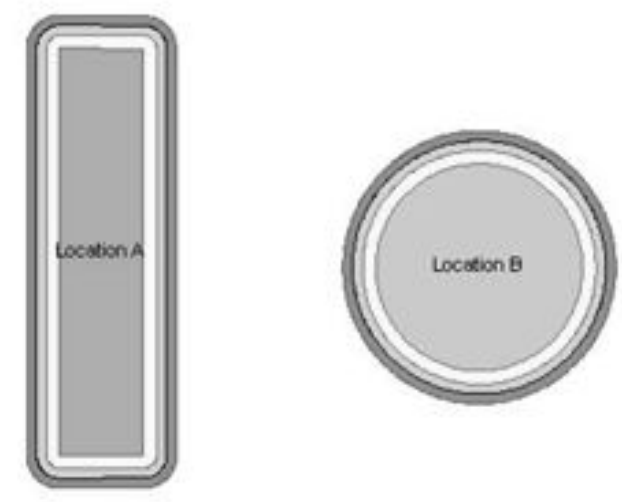

Figure 5. The morphology of 'hypothetical' settlements with similar areal extents.

Table 1. Comparing the effect of morphology on the area included in separation zones. Location A and B are similar in size, but location A is rectangular in shape, whilst Location B is circular.

\begin{tabular}{|c|c|c|c|c|c|}
\hline & & \multicolumn{2}{|c|}{ Location A } & \multicolumn{2}{|c|}{ Location B } \\
\hline & & Area $\left(\mathbf{k m}^{2}\right)$ & $\%$ increase & Area $\left(\mathrm{km}^{2}\right)$ & $\%$ increase \\
\hline \multicolumn{2}{|c|}{ Urban Area } & 7.83 & $\mathrm{n} / \mathrm{a}$ & 7.73 & $\mathrm{n} / \mathrm{a}$ \\
\hline \multirow[t]{3}{*}{ separation zone } & $200 \mathrm{~m}$ & 10.93 & $39.6 \%$ & 9.83 & $27.2 \%$ \\
\hline & $350 \mathrm{~m}$ & 13.41 & $71.3 \%$ & 11.56 & $49.5 \%$ \\
\hline & $500 \mathrm{~m}$ & 16.04 & $104.9 \%$ & 13.44 & $73.9 \%$ \\
\hline
\end{tabular}


The research presented in this paper examines the effect that settlement morphology and resulting separation zone shape have on the availability of shallow coal resources within two coalfield areas of the UK; the South Wales Coalfield, and the Midlands Coalfield in England. The paper builds on research conducted by Jones (2006) by using spatial analysis techniques to examine the degree to which the shape and spatial distribution of settlements within these two coalfields influences the size of separation zones and thus impact access to the shallow coal resources. For the analysis undertaken here, shallow coal resources are those coal deposits at the surface and which constitute relatively closely spaced units of generally thick coals (primary shallow coal resources) or areas in which the coals are generally thinner and less concentrated in vertical and areal distribution (secondary shallow coal resources) but which also have a history of being exploited and continue to be worked, usually on a smaller scale than the primary shallow coal resources.

\subsection{Study area 1: South Wales Coalfield}

The primary and secondary shallow coal resources within the South Wales Coalfield have a combined extent of approximately $1094 \mathrm{~km}^{2}$ (covering 43.1 per cent of the study area). The area extends across parts of Carmarthenshire, Swansea, Neath Port Talbot, Bridgend, Rhondda Cynon Taf, Merthyr Tydfil, Caerphilly, Blaenau Gwent and Torfaen and into South Pembrokeshire (Lott et al. 2006). At its broadest north-south extent, the Coalfield is approximately $30 \mathrm{~km}$ wide and is characterised by several deep valleys running north-south and east-west (Figure 6).

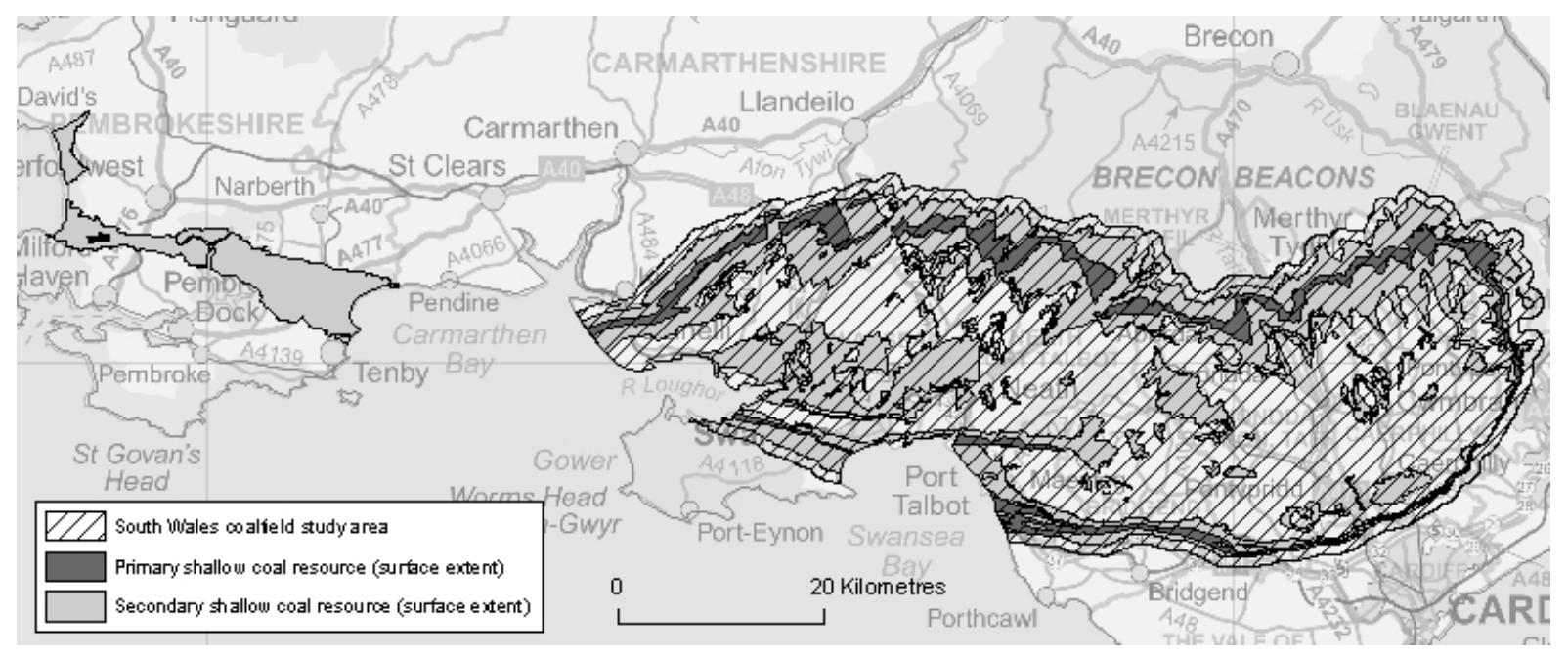

Contains Ordnance Survey data (C Crown copyright and database right 2016. BGS mineral resource data, BGS @ NERC

Figure 6. The surface extent of shallow coal resources within the South Wales Coalfield. Primary shallow coal equates to relatively closely spaced succession of variable but generally thick coals are present at surface. Secondary shallow coal is where coal is present at surface but the coals are generally thinner and less concentrated in vertical and aerial distribution. 
The development of the coal industry in South Wales as one of the premier mining regions of the UK was largely influenced by the presence of high quality coal. Mining began at the edges of the Coalfield where the coal seams outcrop and are thus easier to extract. However, by 1880 and onwards, deeper 'steam' coal was being extracted from nearer the centre of the Coalfield (Bowen, 1941). Although some of the early industrial towns such as Merthyr Tydfil, grew up around existing settlements, many new towns developed as a result of the coal mining, such as Rhondda, and sprang up in previously uninhabited areas. This was especially true in the valleys in the eastern part of the Coalfield. These valleys are typically narrow and steep-sided and, during the height of the industrial revolution, became amongst the most densely populated parts of Britain. Settlements were, therefore, built into tightly packed rows of terraced housing strung out in a linear fashion along the narrow valleys. The development of settlements in the area was, therefore, heavily influenced by geomorphology.

\subsection{Study area 2: Midlands Coalfield}

The Midlands Coalfield comprises the Yorkshire, Nottinghamshire and North Derbyshire coalfields. The primary and secondary (shallow) coal resources within the Midlands Coalfield (Figure 7) have a combined surface area extent of approximately $2393 \mathrm{~km}^{2}$ (covering 82.8 per cent of the study area). Settlements within the Coalfield have seen constant change and development since the industrial revolution which bears testimony to the progressive exploitation of the area. Settlements are not so typically constrained by local geomorphology and tend to be more sprawling and nebulous in morphology than those constrained by the deep valleys of the South Wales Coalfield. 


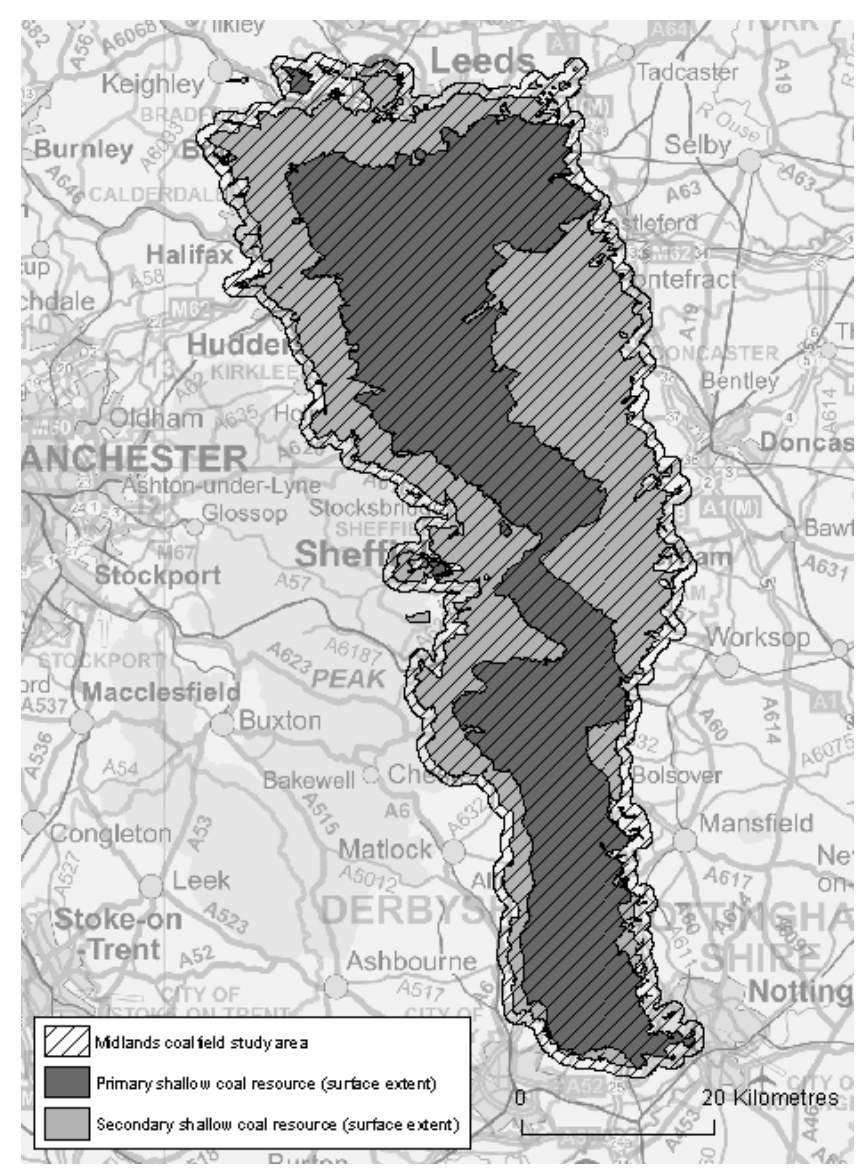

Contains Ordnance Survey data $\odot$ Crown copyright and database right 2016. BGS mineral resource data, BGS @ NERC.

Figure 7. The surface extent of shallow coal resources within the Midlands Coalfield. Primary shallow coal equates to relatively closely spaced succession of variable but generally thick coals are present at surface. Secondary shallow coal is where coal is present at surface but the coals are generally thinner and less concentrated in vertical and aerial distribution.

\section{METHODOLOGY}

\subsection{Determining settlement boundaries}

To ascertain to what degree the shape of settlements influences the size of any separation zone and thus potential to sterilise coal resource, it is first necessary to define a 'settlement' and use this to perform subsequent analyses. The problem of defining settlements has long interested geographers. For example, Cloke (1977) attempted to verify the concept of rurality through the use of Principle Components Analysis to determine an index of rurality. However, according to Thorpe (1964), attempts to make a strong distinction between 'rural' and 'urban' have tended to create more problems than they solve; the boundaries between what is considered to be 'urban' and what is considered to be 'rural' follow a continuum and therefore, blend along it. Furthermore, settlement boundaries will vary over time depending on building activity and population trends (Schoning, 1997). 
For the purposes of this study, the degree of 'urban-ness' or 'rural-ness' is largely irrelevant. It is the distinction between what is considered to be a settlement or not that is important in order to test implications of a applying a separation zone policy. A clear distinction between what constitutes a settlement is required. Settlement areas were, therefore, defined within a Geographical Information System (GIS) using the Ordnance Survey (OS) MasterMap ${ }^{\circledR}$ product and applying a methodology outlined in Lott et al. (2006). The methodology identified whether an individual property forms part of a settlement or is isolated by analysing the minimum separation distance between properties. Where the separation distance is less than $100 \mathrm{~m}$ (i.e. $50 \mathrm{~m}$ from each property), the buildings form a cluster. Clusters of buildings which contain ten or more dwellings are then defined as a settlement (Figure 8). Such an approach has been utilised for other parts of the UK and Europe that have required the delineation of settlement boundaries (e.g Revell, 2004 and Schoning, 1997).

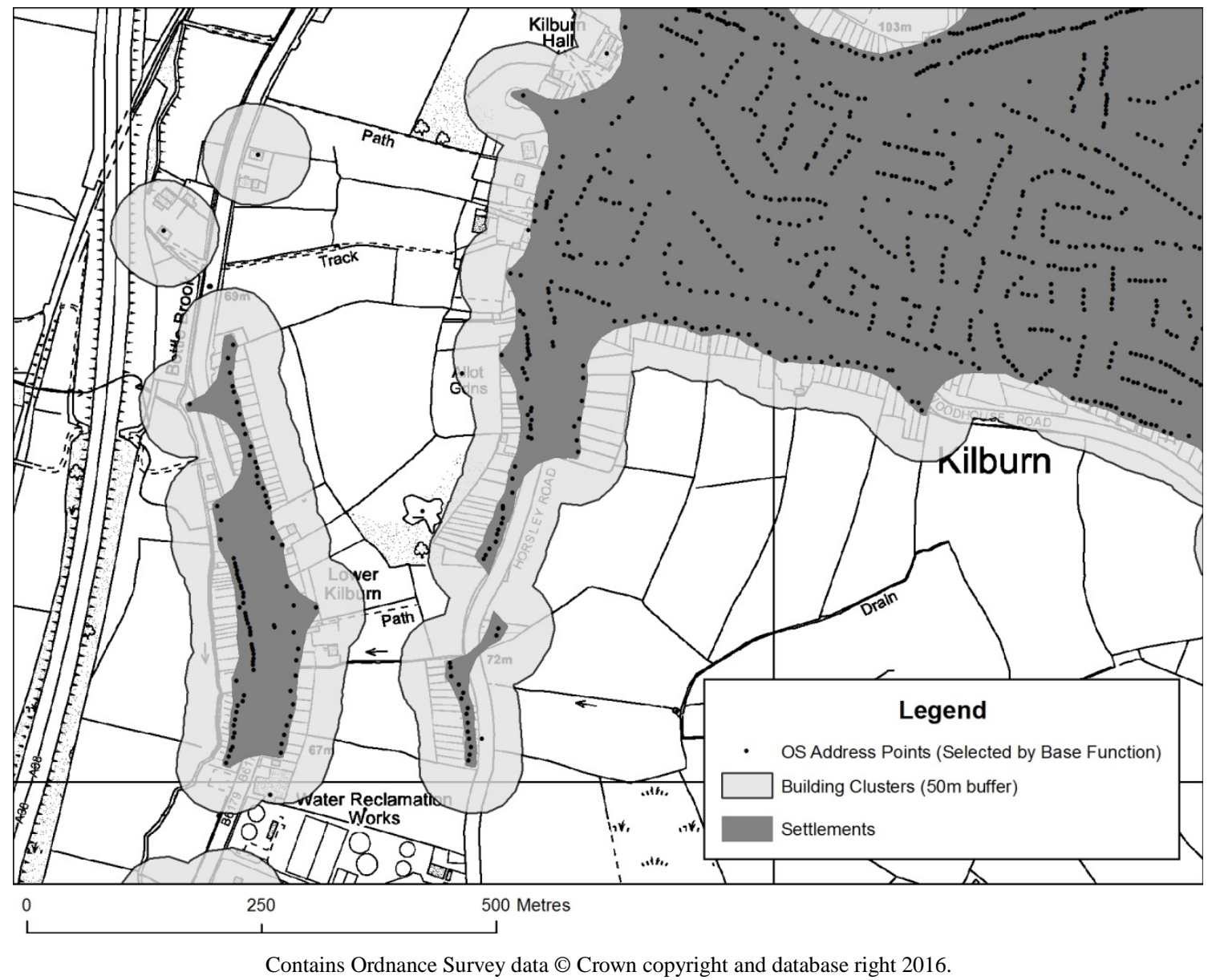

Figure 8. OS Address Points (dwellings) are buffered by $50 \mathrm{~m}$ to produce building clusters (light grey). The buffer is then removed from those building clusters with ten or more dwellings to determine settlement areas (dark grey). 


\subsection{Measuring the shape of settlements}

Shape has always concerned geographers and has been extremely useful for describing towns, physical features, trade areas and political units (Boyce and Clark, 1964). Although GIS technology generally remains quite primitive in describing shape (Wentz, 1997), a number of methods to measure shape, which do not necessarily require the use of a GIS, have been identified in the literature. For example, Bunge (1962) devised a classification system based on measurement of vertices within a shape, whilst Boyce and Clark (1964) base their classification on the measurement of radial distances from a selected point within the shape to the circumference. According to Boyce and Clark (1964) both methods successfully enable shapes to be ranked and, therefore, compared. However, each method has different advantages depending on their application. Other examples exist and are discussed in Wentz (2000). 


\subsection{Qualitative analysis of settlement morphology}

In 2001, the then Department of Transport, Local Government and the Regions (DTLR) commissioned a wide-ranging review of the definitions of urban and rural areas in use for policy purposes and statistical reporting in order to establish and promote a consistent set of urban and rural definitions (DTLR, 2001). The review covered both England and Wales and involved consultation with over twenty-five Government Departments and sections within them. As part of the review, a methodology, developed by Bibby and Shepherd (2001), examined residential densities and compared density profiles of settlements as a means of typifying settlements and enabling, via a set of rules, a classification of settlement types (e.g. small town, village, fringe, peri-urban zone). The methodology uses a GIS to perform a raster (cell) based analysis (i.e. focal mean) of settlements which is based on the premise that the rate at which density falls away from the 'focus' cell is a function of local settlement structure (Figure 9). Thus in a conurbation, where densities are sustained at (say) 30 dwellings to the hectare (or cell) over a broader area, the density profile is unlikely to 'fall-off', whereas for a village in an area of hamlets and isolated dwellings, the density 'fall-off' will be marked.

\begin{tabular}{|l|l|l|l|l|l|l|l|}
\hline 2 & 2 & 3 & 6 & 8 & 9 & 0 & 0 \\
\hline 1 & 1 & 2 & 4 & 4 & 5 & 3 & 1 \\
\hline 0 & 1 & 2 & 3 & 4 & 2 & 0 & 1 \\
\hline 0 & 2 & 1 & 2 & 3 & 4 & 2 & 2 \\
\hline 2 & 2 & 4 & 1 & 3 & 3 & 3 & 3 \\
\hline 1 & 2 & 4 & 2 & 2 & 2 & 3 & 4 \\
\hline 2 & 2 & 2 & 3 & 2 & 1 & 3 & 2 \\
\hline 0 & 1 & 1 & 0 & 1 & 2 & 0 & 3 \\
\hline
\end{tabular}

a) The number of in each cell represents the number of address points within that cell. The Focus Cell is highlighted in dark grey, whilst its $200 \mathrm{~m}$ search neighbourhood is shown in light grey. \begin{tabular}{|l|l|l|l|l|l|l|l|}
\hline 1.5 & 2.3 & 3.3 & 4.6 & 4.8 & 4.1 & 3.3 & 2.3 \\
\hline
\end{tabular}

\begin{tabular}{l|l|l|l|l|l|l|l|}
\hline 1.1 & 1.8 & 2.5 & 3.7 & 4.4 & 3.7 & 2.5 & 1.5 \\
\hline 1.2 & 1.4 & 2.2 & 2.7 & 3.4 & 3.3 & 2.3 & 1.6 \\
\hline
\end{tabular}

\begin{tabular}{|l|l|l|l|l|l|l|l|}
\hline 1.2 & 1.4 & 2.2 & 2.7 & 3.4 & 3.3 & 2.3 & 1.6 \\
\hline
\end{tabular}

\begin{tabular}{|l|l|l|l|l|l|l|l|}
\hline 1.1 & 1.6 & 2.1 & 2.7 & 2.6 & 2.7 & 2.4 & 2.2 \\
\hline
\end{tabular}

\begin{tabular}{|l|l|l|l|l|l|l|l|}
\hline 1.7 & 1.8 & 2.2 & 2.5 & 2.7 & 2.5 & 2.7 & 2.6 \\
\hline 1.7 & 2.2 & 2.1 & 2.2 & 2.3 & 2.6 & 2.3 & 2.8 \\
\hline
\end{tabular}

\begin{tabular}{l|l|l|l|l|l|l|l|}
1.7 & 2.2 & 2.1 & 2.2 & 2.3 & 2.6 & 2.3 & 2.8 \\
\hline 1.5 & 1.8 & 2.1 & 1.8 & 1.9 & 2.0 & 2.3 & 2.4 \\
\hline
\end{tabular}

\begin{tabular}{lllll|l|l|l|l|}
1.5 & 1.8 & 2.1 & 1.8 & 1.9 & 2.0 & 2.3 & 2.4 \\
\hline
\end{tabular}

\begin{tabular}{|l|l|l|l|l|l|l|l|}
\hline 1.2 & 1.3 & 1.6 & 1.6 & 1.3 & 1.6 & 1.9 & 2.3 \\
\hline
\end{tabular}

b) The cells within the search radius are added together and divided by the number of cells in the search radius. This creates a density matrix whereby higher values indicate a more densely populated cell and neighbourhood.

Figure 9. Bibby and Shepherd (2001) methodology uses a GIS to perform a raster based analysis (i.e. a focal mean using a circle radius) of settlements based on the number of address points in each cell and its search neighbourhood. The search neighbourhood in this example is set to 200 metres from the focal cell (d 200). 
Bibby and Shepherd's (2001) methodology has been applied to the two coalfield study areas to provide a useful visual and qualitative analysis of the settlement shapes within the two coalfields (Figure 10 and Figure 11). 'Density profiles' were created using a series of different area or 'window' sizes (i.e. fixed scales), in this case 200 m, 400 m, $800 \mathrm{~m}$ and $1600 \mathrm{~m}$ around each cell and using the OS MasterMap ${ }^{\circledR}$ Address Point layer ${ }^{1}$.

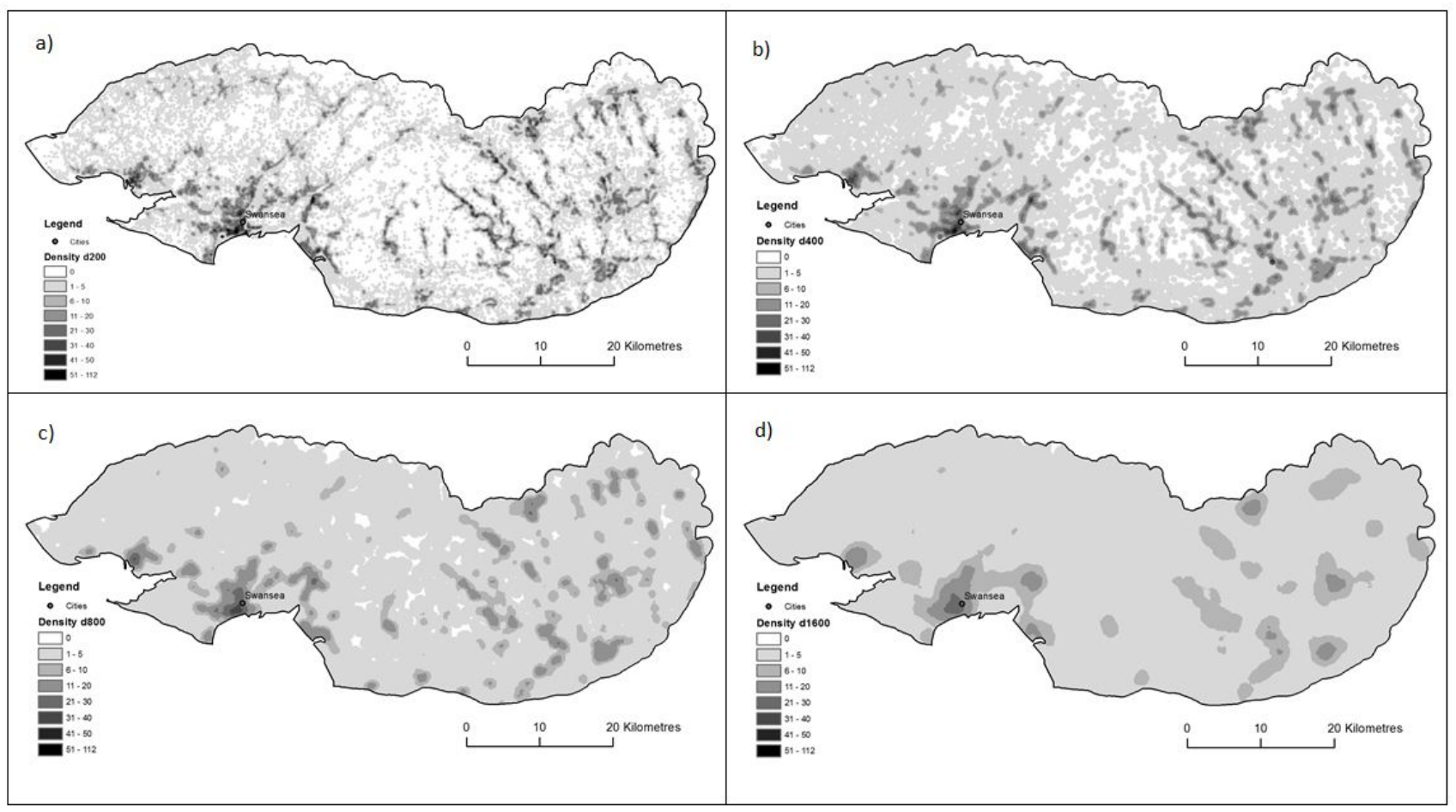

Figure 10. 'Density profiles' for the South Wales Coalfield study area using the methodology applied by Bibby and Shepherd (2001). A series of different area or 'window' sizes (200 m, 400 m, $800 \mathrm{~m}$ and $1600 \mathrm{~m}$ ) have been used around each focus cell. The results are shown in figures a-d respectively.

\footnotetext{
${ }^{1}$ On the $31^{\text {st }}$ October 2014, the Ordnance Survey issued a formal notice of withdrawal of its Address-Point product. OS
} 'AddressBase' will replace this product. 


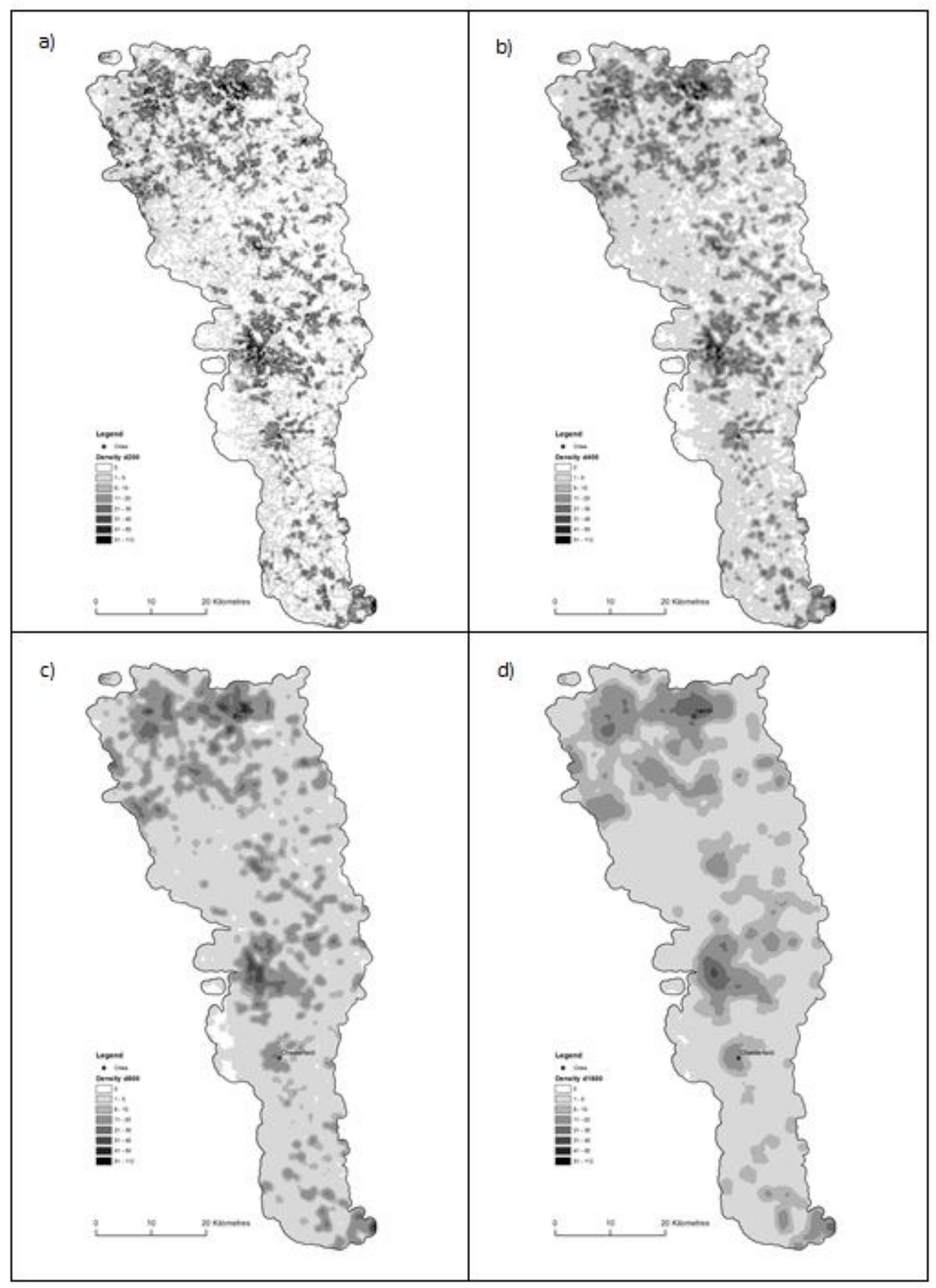

Figure 11. 'Density profiles' for the Midlands Coalfield study area using the methodology applied by Bibby and Shepherd (2001). A series of different area or 'window' sizes (200 m, 400 m, 800 m and $1600 \mathrm{~m}$ ) have been used around each focus cell. The results are shown in figures a-d respectively.

These profiles were then used to calculate the settlement types using Bibby and Shepherd's methodology (Figure 12 and Figure 13). 


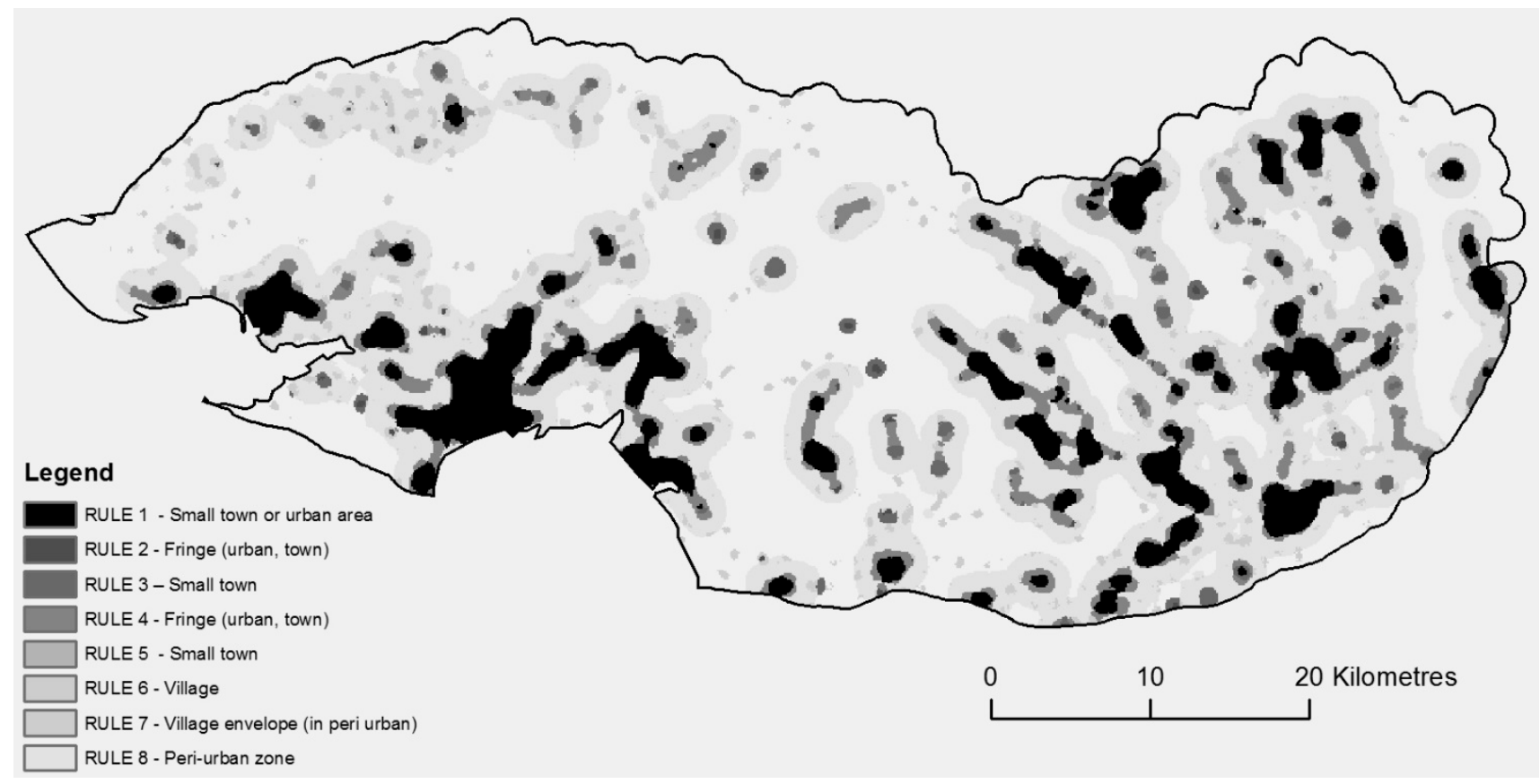

Figure 12. Settlement type in the South Wales Coalfield based on Bibby and Shepherd (2001)

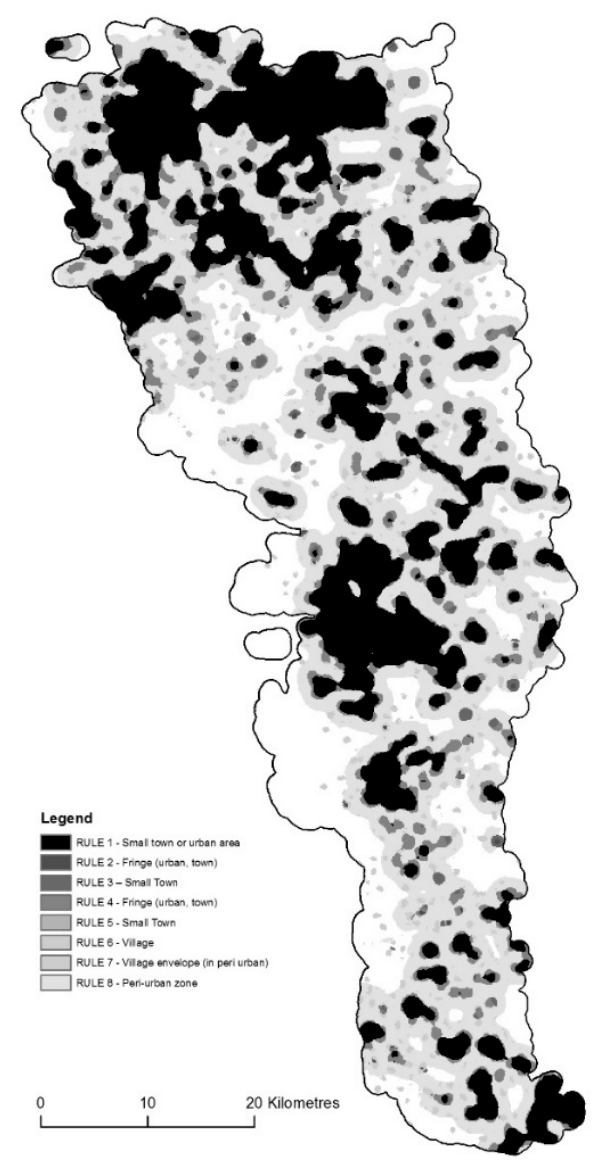

Figure 13. Settlement type in the Midlands Coalfield based on Bibby and Shepherd (2001) 
A visual analysis of the results show that in the South Wales Coalfield the area as a whole is not as densely urbanised as in the Midlands Coalfield. The South Wales Coalfield is also clearly characterised by pockets of 'density' along many valleys, where the majority of settlements exist. This creates settlements with a linear morphology. Whereas in the Midlands Coalfield, the density profiles reveal that not only is the Midlands Coalfield more densely urbanised than the South Wales Coalfield, but that individual settlements are also largely equidimensional in morphology. A more quantitative analysis can confirm whether there are shape differences in the two areas of study.

\subsection{Quantitative analysis of settlement shape}

Perhaps the most simple shape index is a straightforward perimeter-area ratio (PAR). However, a problem with the PAR metric is that it can vary depending on the size of the shape i.e. if two shapes are identical, but one is larger, the PAR will be smaller in the larger shape (McGarigal, 2012). To alleviate the size-dependence problem of the simple PAR, Patton (1975) proposed a shape index which measures the complexity of the shape compared to a standard shape of the same size (McGarigal, 2012). The shape index equation (Equation 1) is based on the geometric principle that a circle has the greatest area and the least perimeter than any other shape. If the perimeter to area ratio of a circle is given a shape index of 1 , then a formula can be derived to calculate a comparable index for any area, to compare its closeness to a circle. This shape index is widely applicable in landscape ecological research, for example, Forman and Godron (1986) use it to describe the shape of lakes in relation to a circle in order to better understand shoreline processes.

\section{Equation 1}

$$
S I=\frac{P}{2 \sqrt{A \pi}}
$$

Where:

SI $\quad=$ The Shape Index.

$P \quad=$ The perimeter of the shape.

$A \quad=$ The area of the shape.

As the purposes of the analysis undertaken in this study is to analyse and describe the shape of urban settlements within two study areas in terms of whether they are deemed to be more elongated or more circular in dimension, the shape index described in Equation 1 is an appropriate measure. To conduct the analysis, five settlements were chosen within each of the two study areas. In order to obtain geometric shapes, without holes, the convex hulls (i.e. the envelope) of each of the selected settlements were compared. An example of a convex hull for two settlements is shown in Figure 14. 

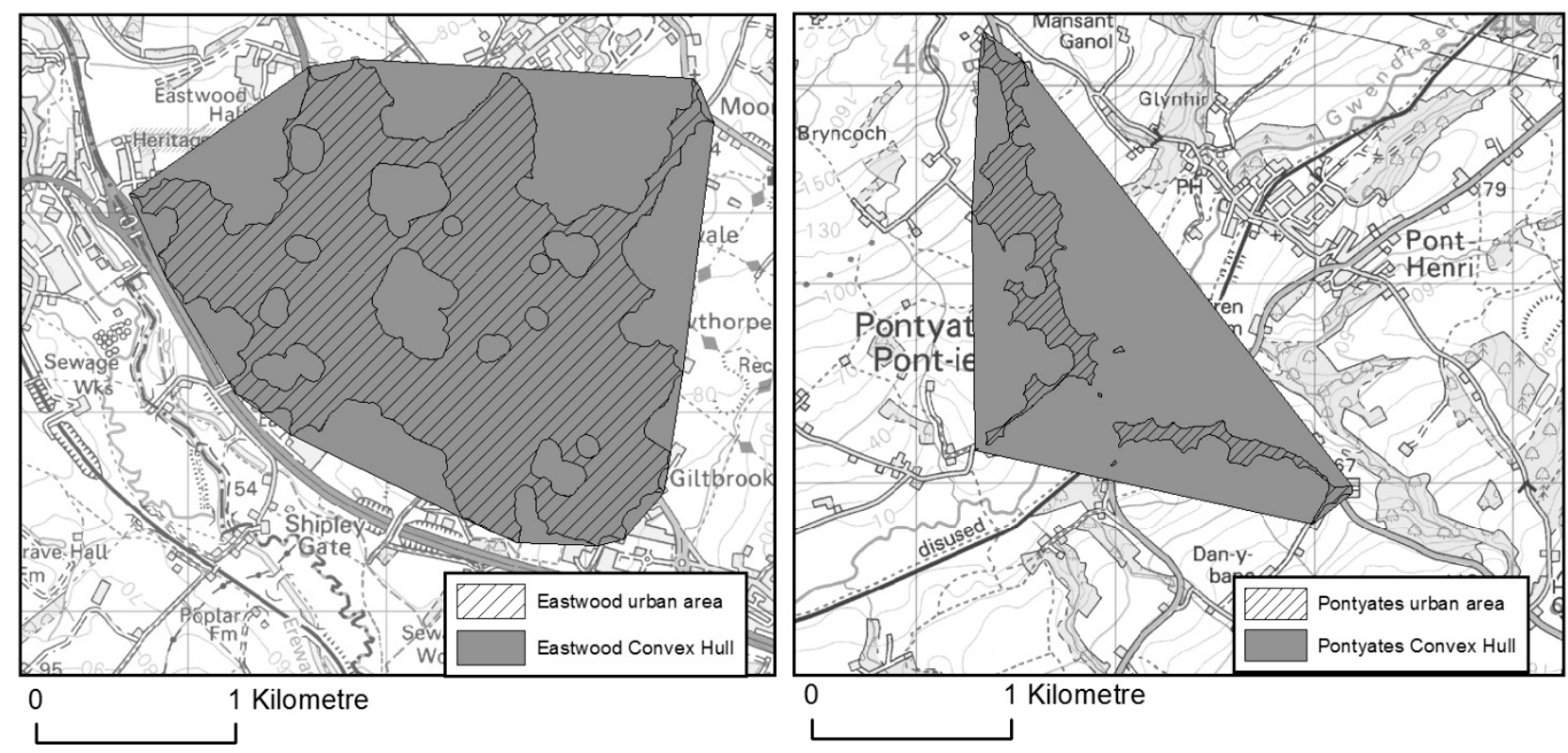

Contains Ordnance Survey data (C Crown copyright and database right 2016.

Figure 14. Demonstrating the convex hull area for Eastwood within the Midlands Coalfield study area and Pontyates within the South Wales Coalfield study area.

\section{Results}

Analysis of the results of the five different sized settlements within each of the two Coalfields (Table 2) shows that the shape index demonstrates all five settlements within the South Wales Coalfield are deemed to be less similar to a circle in shape than the settlements in the Midlands Coalfield study area. This result supports the theory that separation zones applied to settlements within the South Wales Coalfield are likely to be larger in area than the separation zones applied to similarly sized settlements within the Midlands Coalfield. 
Table 2. Comparing the shape of settlements to the shape of a circle using the shape index equation.

\begin{tabular}{|c|c|c|c|c|c|}
\hline Coalfield & Town/City & Area $\left(\mathrm{km}^{2}\right)$ & $\begin{array}{c}\text { Perimeter } \\
\text { (km) } \\
\text { P }\end{array}$ & Shape Index & $\begin{array}{c}\text { Rank (1= } \\
\text { most circle } \\
\text { like, } 10=\text { least } \\
\text { circle like). }\end{array}$ \\
\hline \multirow{5}{*}{$\begin{array}{l}\text { Midlands } \\
\text { Coalfield }\end{array}$} & Eastwood & 5.27 & 8.76 & 1.08 & 2 \\
\hline & Dronfield & 7.48 & 11.18 & 1.15 & 5 \\
\hline & Sheffield & 133.41 & 43.73 & 1.07 & 1 \\
\hline & Conisborough & 4.40 & 8.41 & 1.13 & 4 \\
\hline & Alfreton & 1.99 & 5.50 & 1.10 & 3 \\
\hline \multirow{5}{*}{$\begin{array}{c}\text { South } \\
\text { Wales } \\
\text { Coalfield }\end{array}$} & Maesteg & 18.64 & 20.20 & 1.32 & 7 \\
\hline & Pontycymer & 2.91 & 10.66 & 1.76 & 10 \\
\hline & Pontyates & 2.34 & 7.08 & 1.31 & 6 \\
\hline & Rhondda & 30.51 & 28.49 & 1.46 & 8 \\
\hline & Aberdare & 45.96 & 34.74 & 1.46 & 9 \\
\hline
\end{tabular}

To reinforce this theory, the relative increases in settlement area within the two coalfield study areas when a $500 \mathrm{~m}$ separation zone is applied to them can be analysed.

Table 3 shows that although the combined area of the settlements when a $500 \mathrm{~m}$ separation zone is applied is greater within the Midlands Coalfield (approximately $2000 \mathrm{~km}^{2}$ rather than $1120 \mathrm{~km}^{2}$ ), the relative increase in area, as a result of adding a $500 \mathrm{~m}$ separation zone to the initial settlement area, is greatest in the South Wales Coalfield (559.6 \% increase in area rather than $302.8 \%$ ). 
Table 3. Increase in settlement area within the two coalfield study areas when a $500 \mathrm{~m}$ separation zone is applied.

\begin{tabular}{|l|r|r|r|r|r|r|}
\cline { 2 - 7 } \multicolumn{1}{c|}{} & \multicolumn{3}{c|}{ South Wales Coalfield } & \multicolumn{3}{c|}{ Midlands Coalfield } \\
\cline { 2 - 7 } & \multicolumn{1}{|c|}{$\begin{array}{c}\text { Area } \\
\left.\mathbf{( k m}^{2}\right)\end{array}$} & $\begin{array}{c}\text { As a \% of } \\
\text { settlement } \\
\text { area }\end{array}$ & $\begin{array}{c}\text { As a \% of } \\
\text { study } \\
\text { area }\end{array}$ & $\begin{array}{c}\text { Area } \\
\left.\mathbf{k m}^{2}\right)\end{array}$ & $\begin{array}{c}\text { As a \% of } \\
\text { settlement } \\
\text { area }\end{array}$ & $\begin{array}{c}\text { As a \% of } \\
\text { study } \\
\text { area }\end{array}$ \\
\hline Settlement area & 169.74 & 100 & 6.7 & 496.49 & 100 & 17.2 \\
\hline $\begin{array}{l}\text { Settlement area plus 500 m } \\
\text { separation zone }\end{array}$ & 1119.61 & 659.6 & 44.1 & 1999.75 & 402.8 & \\
\hline $\begin{array}{l}\text { Relative increase in } \\
\text { settlement area as a result of } \\
\text { applying a separation zone }\end{array}$ & 949.87 & 559.6 & 37.4 & 1503.26 & 302.8 & \\
\hline
\end{tabular}

\section{Discussion}

The shape analyses suggests that the shape of a settlement can affect the area included within any potential zone that acts to separate a settlement from proposed surface coal working. Settlements which are elongate in shape will have a larger area of separation zone than proportionally sized settlements which are more geometrically similar to a circle. When the shape index equation was applied to five settlements within each study area (Table 2), the results showed that the all five settlements within the Midlands Coalfield were more geometrically similar to a circle than those settlements analysed within the South Wales Coalfield. The relative impact (in terms of surface area for potential sterilisation) of introducing a separation zone is also greatest in the South Wales Coalfield (Table 3).

Analysis of the settlement density profiles within the Midlands Coalfield (Figure 11) compared to those in the South Wales Coalfield (Figure 10) shows that the Midlands Coalfield is more urbanised than the South Wales Coalfield. GIS area calculations reveal that urban settlements cover 6.7 per cent $\left(169.74 \mathrm{~km}^{2}\right)$ of the extent of the South Wales Coalfield study area whilst in the Midlands Coalfield, settlements cover 17.2 per cent $\left(496.49 \mathrm{~km}^{2}\right)$ of the area. A $500 \mathrm{~m}$ separation zone applied around the settlements in the Midlands Coalfield covers a greater amount of the study area $\left(1999.75 \mathrm{~km}^{2}\right.$ or 69.2 per cent) than in the South Wales Coalfield area (1119.61 $\mathrm{km}^{2}$ or 44.1 per cent), Table 3. The fact that the Midlands Coalfield is more 'urbanised' means that a greater total surface extent of shallow coal resource would be sterilised by the introduction of a $500 \mathrm{~m}$ separation zone than in the South Wales Coalfield (Table 4). If a $500 \mathrm{~m}$ separation zone policy was enforced, approximately $1728 \mathrm{~km}^{2}(72.2 \%)$ of the surface extent of the shallow coal resource would be sterilised by settlements in the Midlands Coalfield and $563 \mathrm{~km}^{2}$ (52.8\%) in South Wales; the total impact is, 
therefore, greater in the Midlands than in South Wales. The overarching reason for this is a consequence of the sheer expanse of settlements within the Midlands Coalfield compared to South Wales rather than settlement morphology (i.e. footprint or shape) specifically. Although all things being equal (as demonstrated in Figure 5 and Table 1), we would expect settlement morphology to influence the area of a separation zone.

Table 4. Areal extent of potential sterilisation of shallow coal resources within two coalfield study areas.

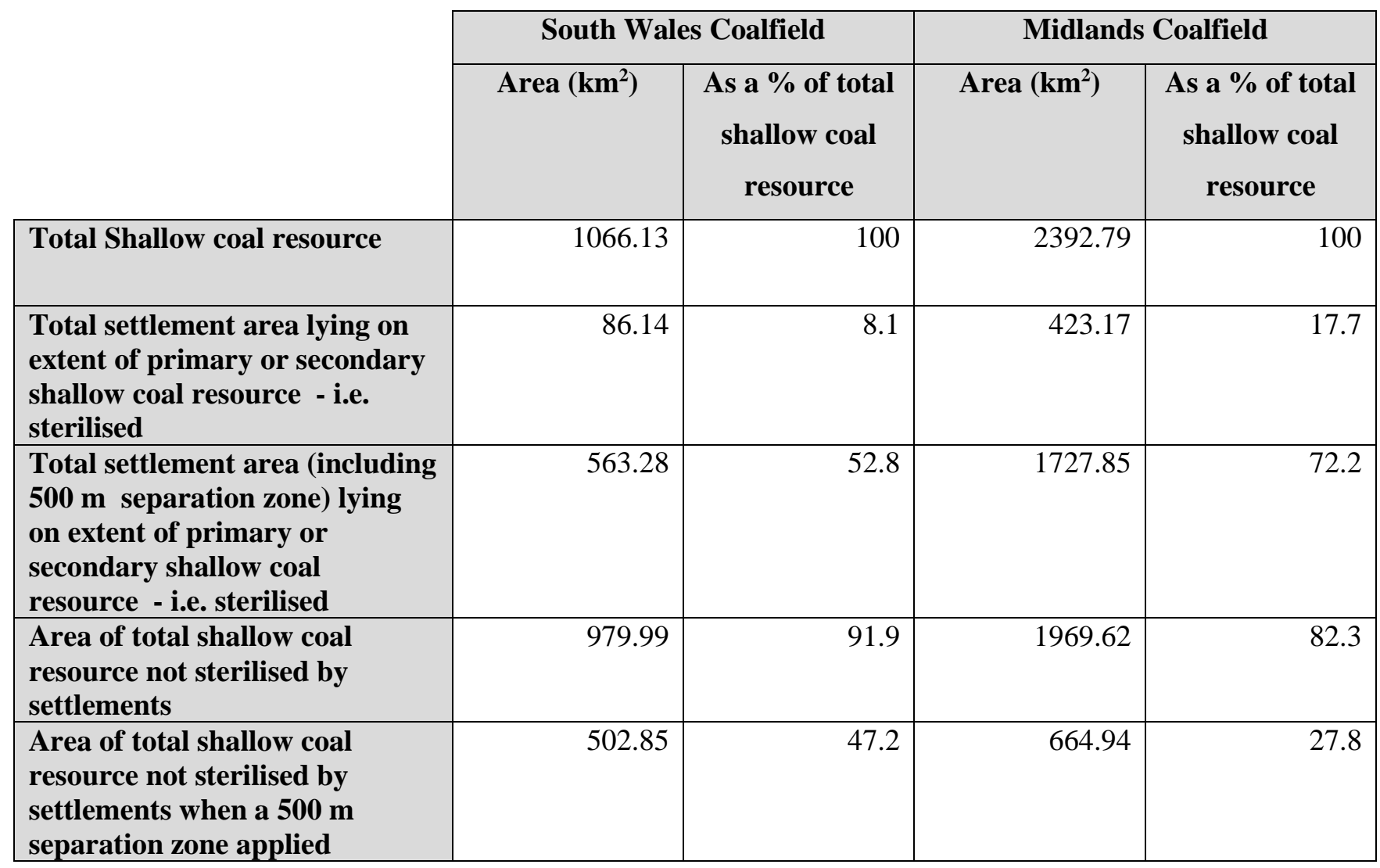

\subsection{Policy Implications}

The UK planning system endeavours to balance the needs of different, and potentially competing, land uses (

2012). This is particularly challenging when operating in coalfield areas which are densely populated and where competition for land can be intense (Bloodworth et al. 2009). The implications of implementing a $500 \mathrm{~m}$ separation zone policy in order to provide a buffer between settlements and coal workings, may be beneficial to the communities within coalfield areas, but conversely may reduce the amount of coal available for extraction and thus conflict with existing policies which are designed to safeguard accessibility to mineral resources (Wrighton et al, 2014). Although the separation zone policies in Scotland and Wales do not necessarily preclude coal mining within $500 \mathrm{~m}$ of a settlement, they may deter development within the specified proximity. The implications of applying a $500 \mathrm{~m}$ separation zone policy (if treated as an outright ban to coal extraction) around 
settlements in South Wales, would reduce the area of available coal resource from approximately $980 \mathrm{~km}^{2}$ (91.9 per cent of the surface extent of shallow coal resource) to $503 \mathrm{~km}^{2}$ (47.2 per cent). In the Midlands Coalfield the effect would be more dramatic, reducing (or sterilising) the area of coal resource from approximately $1969 \mathrm{~km}^{2}$ (82.3 per cent of the surface extent of shallow coal resource) to $665 \mathrm{~km}^{2}$ (27.8 per cent). This is almost ten per cent higher in the Midlands Coalfield than in South Wales Coalfield. This is largely due to the sheer expanse of settlements within the Midlands Coalfield rather than their morphology specifically.

\section{Conclusions}

Identifying sites suitable for surface coal working will depend not only on where shallow coal resource exists, but also where the planning system permits development. Although policies exist in both Scotland and Wales to protect coal workings encroaching too closely to settlements, no equivalent policy exists in England.

Although these policies do not necessarily prevent coal development within $500 \mathrm{~m}$ from a settlement, where they are in place, applications are "unlikely to be acceptable". If an outright ban on the working of shallow coal within $500 \mathrm{~m}$ of a settlement is assumed, the surface extent of the coal resource deemed to be available (i.e. not sterilised) is significantly reduced. The shape of a settlement's footprint (i.e. its morphology) influences the total surface area of its separation zone. Consequently, settlement morphology has the potential to affect the surface area of shallow coal resource sterilised. Elongated settlements, such as those found in the South Wales Coalfield, have a greater influence on the area of its separation zone than similarly sized geometrically more circular settlements, such as those found in the Midlands Coalfield.

In practice, the effect of applying a 500m separation zone policy clearly differs in different places. Although some settlements within the Midlands Coalfield can be quantified as being more geometrically circular than in the South Wales Coalfield, it does not necessarily follow that the impact of implementing a separation zone policy will be greater in the South Wales Coalfield. Analysis demonstrates that the extent of potential sterilisation of the shallow coal resources within the two areas, through application of separation zones, is considerably greater within the Midlands Coalfield. This is mostly because of the difference in urban density of the two areas rather than the typical morphology of the settlements found in each area. The Midland Coalfield is far more densely urbanised than the South Wales Coalfield and as such any separation zone applied will overlie more shallow coal resource. 


\section{REFERENCES}

Bibby, P., and Shepherd, J. 2001. Developing a new classification of urban and rural areas for policy purposes - the methodology. Available online at https://www.gov.uk/government/uploads/system/uploads/attachment_data/file/137655/rural-urbandefinition-methodology-technical.pdf. Accessed 08 Jan 2016.

Bloodworth, A J, Scott, P W and McEvoy, F M. 2009. Digging the backyard: Mining and quarrying in the UK and their impact on future land use. Land Use Policy.

Bowen, E.G., 1941. Wales: A study in geography and history. Cardiff, University Of Wales Press Board p182.

Boyce, R. and Clark, W. A .V. 1964. The concept of shape in geography. Geographical Review, Oct 1964, Vol. 54, no.4. p. 561-572.

British Geological Survey. 2010. Mineral Planning Factsheet: Coal. Available online at: http://www.bgs.ac.uk/mineralsuk/planning/mineralPlanningFactsheets.html. Accessed 08 Jan 2016.

British Parliament. 2008. Climate Change Act. 2008. Available online at: http://www.legislation.gov.uk/ukpga/2008/27/pdfs/ukpga_20080027_en.pdf. Accessed 08 Jan 2016.

Bunge, W., 1962. Theoretical Geography. First Edition. Lund Studies in Geography Series C: General and Mathematical Geography. Lund, Sweden: Gleerup.

Chapman, G. R., Highley, D. E., Cameron, D. G., Norton, G. E., Taylor, L. E. and Lusty, P. A. J. 2006. Summary of information on coal for land-use planning purposes. British Geological Survey Report, CR/06/114N 35 pp. Available online at: http://nora.nerc.ac.uk/7454/1/CR06114N.pdf. Accessed 08 Jan 2016.

Cloke, P. J., 1977. An index of rurality for England and Wales. Regional Studies Volume 11, Issue 1. 21-46. DOI: 10.1080/09595237700185041.

Department for Communities and Local Government (DCLG). 2012. National Planning Policy Framework (NPPF). ISBN:978-1-40983413-7. Available online at: http://www.communities.gov.uk/documents/planningandbuilding/pdf/2116950.pdf. Accessed 08 Jan 2016.

Department of Energy and Climate Change (DECC). 2014a. Energy trends: March 2013, special feature articles - coal in 2013. Available online at:

https://www.gov.uk/government/uploads/system/uploads/attachment_data/file/357548/Coal_2013.pd f. Accessed 08 Jan 2016.

Department of Energy and Climate Change (DECC). 2014b. Solid fuels and derived gases: Chapter 2. Digest of United Kingdom Energy Statistics (DUKES). Table: Deep mines and surface mines in production. December 2014 (DUKES 2.7). Available online at:

https://www.gov.uk/government/statistics/solid-fuels-and-derived-gases-chapter-2-digest-of-unitedkingdom-energy-statistics-dukes. Accessed 07 Jan 2016.

Department of Energy and Climate Change (DECC). 2015a. Energy: Chapter 1, Digest of United Kingdom Energy Statistics (DUKES). Table: Aggregate energy balances (DUKES 1.1-1.3). 
Available online at: https://www.gov.uk/government/statistics/energy-chapter-1-digest-of-unitedkingdom-energy-statistics-dukes. Accessed 07 Jan 2016.

Department of Energy and Climate Change (DECC). 2015c. Digest of United Kingdom Energy Statistics (DUKES). Table: 1.1.1: Inland consumption of primary fuels and equivalents for energy use, 1970 to 2014. (DUKES 1.1.1) Available online at:

https://www.gov.uk/government/uploads/system/uploads/attachment_data/file/338781/Long_Term_T rends.pdf. Accessed 07 Jan 2016.

Department of Energy and Climate Change (DECC). 2015b. Digest of United Kingdom Energy Statistics (DUKES) 2015. Chapter 1: Energy. Available online at:

https://www.gov.uk/government/uploads/system/uploads/attachment_data/file/447628/DUKES_2015 _Chapter_1.pdf . Accessed 08 Jan 2016.

Department of Natural Resources, Queensland. 1997. Planning Guidelines: separating agricultural and residential land uses. Available online at: https://www.dilgp.qld.gov.au/resources/policy/plngguide-sep-ag.pdf. Accessed 12 April 2017.

Department for Environment, Food and Rural Affairs (DEFRA). 2010. Environmental permitting guidance; The large Combustion Plants Directive for the environmental permitting (England and Wales) regulations 2010. Version 3.0. Available online at: https://www.gov.uk/government/uploads/system/uploads/attachment_data/file/69327/pb13635ep2010combustionplants.pdf. Accessed 08 Jan 2016.

Department of Transport, Local Government and the Regions (DTLR). 2001. A review of urban and rural area definitions, project report. Available online at:

http://www.willamette.edu/cla/debate/pdf/youth_forum/mtt\%20research/cultural\%20advantages/Elvi ra_Project_20Report_22_20AugONS.pdf. Accessed 08 Jan 2016.

European Parliament. 2001. Directive (2001/80/EC) on the limitation of emissions of certain pollutants into the air from large combustion plants. Available online at: http://eurlex.europa.eu/legal-content/EN/TXT/?uri=CELEX:32001L0080. Accessed 08 Jan 2016.

European Parliament. 2011. Directive (2011/92/EU) on the assessment of the effects of certain public and private projects on the environment. Available online at:

http://ec.europa.eu/environment/eia/pdf/EIA_Directive_informal.pdf. Accessed 15 Feb 2017.

Forman, R.T.T. and Godron, M., 1986. Landscape Ecology. John Wiley \& Sons. ISBN 0-471-870374 pp 619.

Hammond, G. P. and Spargo, J. 2014. The prospects for coal-fired power plants with carbon capture and storage: a UK perspective. Energy Conversion and Management Volume 86, Pages 476-489. http://www.sciencedirect.com/science/article/pii/S0196890414004415. Accessed 08 Jan 2016.

House of Commons. 2011a. Planning (Opencast Mining Separation Zones) Bill. Bill 15. Available online at: http://www.publications.parliament.uk/pa/bills/cbill/2010-2011/0015/2011015.pdf Accessed 08 Jan 2016.

House of Commons. 2011b. Planning (Opencast Mining Separation Zones) Bill. Bill 15. Explanatory notes. Available online at: http://www.publications.parliament.uk/pa/bills/cbill/20102011/0015/en/2011015en.pdf. Accessed 16 Jul 2015. 
Jones, N.S., 2006. A pilot study to show the effects of separation zones around urban areas on opencast coal resources for the SK47 area, north Derbyshire, UK. British Geological Survey Commissioned Report CR/006/158.

Lott, G.K., Jones, N.S., Adlam, K.A., Garcia-Bajo, M.., Williams, N., Cooper, R. And Linley, K. 2006. Safeguarding Opencast Coal Resources in the Welsh Coalfields. British Geological Survey Commissioned Report. CR/06/175.

McGarigal, K. 2012. FRAGSTATS - Spatial Pattern Analysis Program for Categorical Maps. FRAGSTATS Metrics. University of Massachusetts. Available online at:http://www.umass.edu/landeco/research/fragstats/documents/Metrics/Shape\%20Metrics/FRAGST ATS\%20Metrics.htm. Accessed 08 Jan 2016.

Patton, D.R., 1975. A diversity index for quantifying habitat "Edge”. Wildlife society bulletin, Vol. 3. No 4. p171-173.

Revell, P. 2004. Building on Past Achievements: Generalising OS MasterMap® Rural Buildings to 1:50 000. ICA Workshop on "Generalisation and Multiple representation”, 20-21 August 2004, Leicester. Available online at:

http://icaci.org/files/documents/ICC_proceedings/ICC2005/htm/pdf/oral/TEMA9/Session\%204/PATRICK\%2 0REVELL.pdf. Accessed 08 Jan 2016.

Schoning, P., 1997. Land use statistics for cities and urban settlements in Norway, Conference of European statisticians, work session on Geographical Information systems. Available online at: http://www.unece.org/stats/documents/1997/09/gis/18.e.pdf. Accessed 08 Jan 2016.

The Stationary Office (TSO). 2013. Energy Act. Available online at: http://www.legislation.gov.uk/ukpga/2013/32/pdfs/ukpga_20130032_en.pdf. Accessed 08 Jan 2016.

Thorpe. 1964. Rural settlement, in Watson, J.W., and Sissons, J.B., (Eds), The British Isles?: A systematic Geography, Nelson, London. pp452. ISBN 13: 9780177110146.

The Scottish Government. 2014. Scottish Planning Policy (SPP) Available online at: http://www.gov.scot/Resource/0045/00453827.pdf. Accessed 08 Jan 2016.

UK Minerals Forum (UKMF). 2014a. Trends in UK Production of Minerals. UK Minerals Forum Working Group 2013 - 14 - Future Mineral Scenarios for the UK). Available online at: http://nora.nerc.ac.uk/508895/1/UK\%20Minerals\%20Forum\%20\%20Trends\%20in\%20UK\%20Production\%20of\%20Minerals_14022014.pdf. Accessed 08 Jan 2016.

UK Minerals Forum (UKMF). 2014b. Future Minerals Scenarios for the UK, UK Minerals Forum Working Group 2013 - 14. ). Available online at:

http://nora.nerc.ac.uk/508896/1/UK\%20Minerals\%20Forum\%20Futures\%20Working\%20Group\%20 -\%20Final\%20Report\%2008102014.pdf. Accessed 08 Jan 2016.

Welsh Assembly Government. 2009, Minerals Technical Advice Note (MTAN) 2: Coal. Available online at: http://gov.wales/docs/desh/policy/090120coalmtanen.pdf. Accessed 08 Jan 2016.

Wentz, E. A., 1997. Shape Analysis and GIS. Auto-Carto 13, 204-13.

Wentz E. A., 2000. Shape Definition for Geographic Applications Based on Edge, Elongation, and Perforation. Geographical Analysis, Vol. 32, No 1. 95-112. 
Western Australian Planning Commission, Department of Planning. 2016. State Planning Policy 2.5 Rural planning Guidelines Version 3. Available online at:

https://www.planning.wa.gov.au/dop_pub_pdf/Rural_Planning_Guidelines_2016.pdf. Accessed 12 April 2017.

Wagner, H., Tiess, G., Solar, S., Nielsen, K., 2006. Minerals Planning Policies in Europe. RMZ Mater. Geoenviron. 52, 607-620. Available online at: 〈http://www.rmzmg.com/letniki/rmz52/rmz52_0607-0620.pdf $\rangle$. Accessed 14 Feb 2017.

Wrighton, C E, Bee, E J, and Mankelow, J M. 2014. The development and implementation of mineral safeguarding policies at national and local levels in the United Kingdom. Resources Policy, Vol. 41, 160-170. Available online at: http://dx.doi.org/10.1016/j.resourpol.2014.05.006. Accessed 08 Jan 2016.

The authors publish this article with the permission of the Executive Director, British Geological Survey (BGS), Natural Environment Research Council (NERC). This paper has been published as a result of initial research conducted by the British Geological Survey for the Department for Communities and Local Government. Whilst every effort has been made to ensure the accuracy of the material in this paper, the authors will not be liable for any loss or damages incurred through the use of this paper. We would like to acknowledge our colleagues Geraldine Wildman and Ed Hough who reviewed this article prior to submission. 